\title{
Hajnády Zoltán
}

\section{Szakrális és démonikus nőalakok orosz poétikai kontextusban}

\author{
Il n'y a pas d'oeuvre d'art sans collaboration du démon. ${ }^{1}$ \\ André Gide \\ Tout est éprouvé par son contraire. ${ }^{2}$ \\ Vlagyimir Szolovjov
}

A dualitás az európai gondolkodásban szinte mindenben jelen van: lét-nemlét, jó-rossz, szép-rút, szakrális-profán, ahol a fogalompár első tagja mindig pozitívumot és a lényeget jelenti, a második tagja pedig a negatívumot és az első tagadását. A feloldhatatlannak tünő ellentétek kölcsönösen feltételezik egymást. A pozitív archetípus spontán módon generálja negatív ellenpólusát. Minden mindenkor magában hordja az ellentétét is. Az ellentétes minőségü ellentétpárok valójában egymásrautaltsági viszonyban állnak egymással. Még az is kérdéses, hogy egyiknek a másiktól függetlenül van-e létjogosultsága. Egyik fél sem léphet föl egyedül mint saját maga, hanem mindig csak úgy, mint a másik szubsztanciális párja, amely nélkül nincs teljesség.

Az orosz irodalom nőközpontú, az életet és a létezést fenntartó nő áll a középpontjában. Cselekményének mozgatórugója a nőalakok értelmezése. A hős próbatétele az, hogy képes-e meglátni a hősnő belső ragyogását. Az eszményt is a női szépség ábrázolásán keresztül fejezi ki. „A nőt azért imádjuk, mert uralkodik eszményi ábrándunkon." ${ }^{3} \mathrm{~A}$ női princípium első helyen való szerepeltetését könyvem és tanulmányom címében nem az udvariasság diktálta, hanem a férfiak fölé nőtt női nagyság. A sorrendiség megváltoztatása (anafrázis) az orosz kultúra anima-elvűségét, az apai felett az anyai dominanciáját hivatott hangsúlyozni, amit Nyikolaj Bergyajev az orosz lélek "örök asszonyiságának" nevezett. Ezért fordítottam meg a hagyományos Logosz-Szophia sorrendet, amelyet felfoghatunk úgy is, mint az örök női princípium győzelmét a patriarchális szemlélet fölött. ${ }^{4}$

Az alkotást a mindent átfogó és megtartó feminin elv szabályozza, amelyből minden ered. A teremtő istenségnek mint az élet ősforrásának joggal tulajdonítanak anyai vonásokat. A termékenységi tulajdonságokkal felruházott istennőket ősidőktől fogva nem a szépségükért, hanem az önmagukban teremtő női erőért imádták. Az orosz kultúrában a nőiség szentesített, vallásos változata magába szívta a termékeny Földanya-mítoszát. ${ }^{5}$ Az életet adó ősanyának mint a női lét soha meg nem szűnő legtitokzatosabb képességének nemcsak kultikus-szakrális változata létezik, hanem vannak profán, démonikus transzformációi is. Ő Pandora, aki a tiltott szelencét kinyitotta, és ezzel a világ minden baját rázúdította az emberiségre. Ő az eredendő bűn forrása, Éva lánya, de Mária gyermeke is, aki a megváltás keresésére ösztönözi a férfit. Többé már nem a bűn hordozója. „Most is csábítok, de a fény felé. Vonzok mindig, de már a szabadságba. Én ezentúl a Szüzesség vagyok" (Teilhard de Chardin). ${ }^{6}$ A nő a szerelem, a termékenység, a nemzet any- 
jának a megtestesítője, világanya, de olykor viszályt szító Erisz istennő, aki egyszerre tárgya hódolatunknak és félelmünknek. A démonit azonban nem kell megalázó és diadalmas ellenségnek tekinteni, hanem olyan erőnek, amely az egésznek szerves része. A rossz pozitív cselekvő erőként is megnyilvánulhat, amely éppen a jó erőtlenségére válaszul fejlődik ki.7 Az orosz írók nagy erőssége a rossz, a gonosz iránti fogékonyság, ami megóvta őket a valóság megszépítésétől, az idealizálás veszélyeitől. Lehetővé tette számukra, hogy az emberi lét valamennyi oldalával szembenézzenek, beleértve a sötétet és démonit is; a szereplőket ne csak síkban, hanem mélységi vertikumban ábrázolják.

Az orosz irodalom tele van gyenge akaratú, passzív, szemlélődő férfiakkal, ugyanakkor bővelkedik cselekvő nőalakokban, akik gyakran a férfi jellemének a próbaköveként jelennek meg, egy sajátos tükörként, amely önismeretre vezeti azokat, akik belepillantanak. Ezek a szláv lelkű Fauszták olykor még a sötétség fejedelmével, a Sátánnal is szövetségre lépnek céljuk elérése érdekében, a rosszat is jóra használják (lásd Margarita pokoljárását Mihail Bulgakov regényében). Az orosz írók megrajzolták az orosz nő emblematikus arculatát, amely sok vonatkozásban különbözik a L'éternel féminin fogalmától. Az európai szerelem patetikus, az orosz démonikus. „Az orosz irodalom nem ismer olyan gyönyörű szerelmes alakokat, mint a nyugat-európai irodalom. Nálunk semmi sincs, ami hasonlítana a trubadúrok szerelméhez, Trisztán és Izolda, Dante és Beatrice, Rómeó és Júlia szerelméhez. A férfi és a nő szerelme, a nő szerelmi kultusza Európa keresztény kultúrájának gyönyörű virága. Mi nem éltük át a lovagkort, nálunk nem voltak trubadúrok. Ez veszteséget jelent szellemünk számára. Az orosz szerelemben van valami súlyos és kínzó, borús és gyakran rút. Nem volt nálunk igazi romantika a szerelemben. A romantika nyugat-európai jelenség." ${ }^{\prime 8} \mathrm{Az}$ orosz irodalomban gyakoriak a szabadság határait mások rovására önkényesen átlépő voluntarista hősök, akik vélt igazuk miatt a számukra legkedvesebb embert ölik meg: Aleko Zemfirát, a Démon Tamarát, Rogozsin Nasztaszja Filippovnát. Erről szól Tyutcsev verse:

Óh, milyen gyilkos a szerelmünk

míg a vak szenvedély sodort,

legjobban azt kellett megölnünk,

mi szívünk legföbb kincse volt!

(Szabó Lőrinc fordítása)

Jelen tanulmány a női princípium két archetípusát, a szakrális és démoni nőalakok jelentését vizsgálja orosz poétikai szövegkörnyezetben, evidensnek tartva, hogy az ezerarcú nő nem szűkíthető le csupán erre a két archetípusra.

Jung szerint a női princípium három archetípusban ölt testet: anyai, csábító és démonikus. Puskin műveiben anyja egyetlenegyszer sem szerepel. A csábító-kísértő démon sötét szelleme viszont nála is felbukkan. Puskin a női lélek fényes oldalát emelte ki, nem a sötétet. Nála az anima olyan dualitásával ritkán találkozunk, mint amilyen Lermontovnál és Dosztojevszkijnél fordul elő. Démonikus femme fatale alakjai közül csak Kleopátra és Zaréma szépsége egyszerre vonzó és taszító. Kleopátra, az azonos című versben és az Egyiptomi éjszakák című elbeszélésben hódolóit szerelmi viadalra hívja (meghívás kivégzésre). A sors istennőjének szerepét játssza, aki kezében tartja szeretői életfonalát: „Aki megfizeti 
az árat, / Annak adok egy éjszakát. / Az életével éjszakámat / Ki veszi meg, lássuk tehát!" (Lothár László fordítása.) „Az életemet egyetlen éjszakáért” hőse, az örökléttel egyenértékű, felfokozott pillanat kedvéért lemond az örökkévalóságról. "Megízlelve a méz egy cseppjét, azon nyomban meghalok" (1 Kir 14:43). ${ }^{9}$ Romantikus felfogás szerint a végtelen a végesben is átélhető: „Ewigkeit in Zeit.”

Puskin úgy szólt a nőkről, ahogyan még senki sem beszélt róluk az orosz irodalomban. Vallásosmetafizikai jelentést tulajdonított a szépségnek. Verseiben az égi Madonna földi alakot ölt, a szeretett földi asszony pedig égi magasságokba emelkedik. Egyik versében Raffaello Sixtusi Madonnáját idézi, másik versének, amelyet világszép menyasszonyához írt, Madonna a címe. Számára Erósz egyszerre jelenti a földi-érzéki szenvedélyt és a minden érzékiségtől mentes szerelmet. Lelke a két véglet, Venus vulgaris és Venus caelestis között őrlődött. Előbbi szépsége a női testben mutatkozik meg, utóbbié a lélekben. Puskin nemcsak a női testet, hanem annak platóni eszméjét, az örök nőiség animáját, éteri auráját ragadta meg, mert a szépség mindig eszményi. Így volt ez már $A$ bahcsiszeráji szökőkút című poémában is, ahol a szenvedélyes grúz Zaréma a földi, a tatár kán által elrabolt, angyalian szelíd lengyel Mária pedig az égi vonzalmat hivatott képviselni. Vonatkozik ez a megállapítás a Még bennem él a perc varázsa című versre is, hiszen tudjuk, hogy a címzett, Anna Kern, nem volt a szűztiszta szépség földi mása. Puskin megunt kedvesét egyenesen „babiloni szajhának” nevezte, de mégiscsak az ő testén keresztül vezetett az út az égi szerelemhez. Puskin minden nőben az eszményi nőt kereste, összekapcsolta az emberi lét két oldalát: az immanens valóságot a transzcendenssel. Alig észrevehető az átmenet a konkrét, helyhez kötött és az időtlen, általános között. Szinte zavarba ejtő, hogyan ad kétféle értelmet egyazon dolognak. Számára a szépség egyszerre halandó nő és halhatatlan istennő, aki a testiségről és a szerelemről képes magasabb fogalmat nyújtani. Egyik szeme Vénuszt nézi, a másik Madonnát. Az előbbi látványa a szemet igézi meg, utóbbi a lelket ejti rabul. A fizikai szerelem fölébreszti a metafizikai szerelem utáni vágyat. A költészet számára nem trubadúr nőszolgálat: „Milton és Dante sem a szebbik nem nyájas mosolyáért írtak." ${ }^{10}$ Puskin költészetét sóvárgó vágyakozás hatja át a Szophia-mosoly után, amely megszabadít a földi szenvedélyektől. Ezt a rejtélyes és megejtő mosolyt, amely az Abszolútum utáni vágyat fejezi ki, emberi nőkön nem lehet tapasztalni, csak Szophia-ikonokon. Szerelmes verseinek lényege nem egy meghatározott nőre, hanem a végtelen számú testben megvalósuló örök asszonyira irányul, akinek istenarca áttűnik a szeretett földi lény vonásain. „Puskin szenvedélyes érzékisége - amely tragikus életérzésének egyik forrása - vallásos érzékiségbe hajlik. Nem tud a »szépségre meghatottság nélkül nézni«: a tökéletes női szépség számára valami olyasmi, ami »fölötte áll a világnak és a szenvedélyeknek«, amelynek szemlélése közben »imádságos tisztelettel hajt fejet a szépség szentsége előtt«."11

Metafizikus költészetének kimagasló darabja az Élt a földön egy szegény lovag című rejtélyes poéma, melynek hőse Szűz Máriának ajánlja fel az életét, s hű marad fogadalmához. Puskin nőalakjai közuil Isten anyja képviseli a legmagasabb szintet, aki minden szexualitástól mentes felsőbbrendű női princípium. A szerzeteslovag szíve hölgyét vallási rajongással szereti, „égi fénynek, szent Rózsának” nevezi. A versben a lovagi etikett illemszabályai ötvöződnek a katolikus szertartásban használt latin nyelvü köszöntési formákkal: Ave Mater Dei $\langle. .$.$\rangle Lumen coelum, sancta Rosa! A lovagi nőkultusz és a Mária-kultusz szálainak összesodrásával$ Puskin ősi rituális szertartást követ. A szenvedélyes szerelem (amour passion) észrevétlenül alakul át az Istenanya iránti áhítatba (amor sanctus). ${ }^{12} \mathrm{~A}$ szerzeteslovag sisakrostélyát leereszti, földi nőre nem néz többet, tekintetét a mennyei szép felé fordítja, pajzsára három betűt ír fel a vérével: A. M. D. 
Az eszményképhez való hűség és önfeláldozás eszméje áthatja Puskin egész költészetét, az erotikus témájúakat is. Mindez hatott Dosztojevszkij szépség-felfogására, ${ }_{13}^{13}$ Szolovjov Szophia-tanára.

Puskin Tatyjánája, Turgenyev Lizája, Tolsztoj Natasája a feltétlen szépség megtestesítői, az orosz nő apoteózisai. Mindegyikükben a női univerzum egy-egy vonása testesült meg. Az eszményi szépet azonban nem lehet árnyék nélkül ábrázolni. Minden földi szépségben van valami ördögi, ellene még az angyalok sem tudtak védekezni, fellázadtak és az emberek leányaival szerelembe estek. ${ }^{14} \mathrm{~A}$ női varázs az angyaloktól szerzett tudás előtt tiszta volt, csak később változott démonivá. Ha a külső szépség és a belső tartalom nem felel meg egymásnak, az a démoni. Lermontov egyik versében ez áll: „Szép külseje angyali lányé, de démoni lelke gonosz" (ford. Lator László). ${ }^{15} \mathrm{Az}$ Isten ellen lázadó angyalok számára az égi világból a földi szférába való átlépés tragikus következményekkel járt: „Mardosta, gyötörte soká a csodás, / földöntúli vágyakozás. / A föld üres éneke néki mit ért / cserébe a mennyeiért?" (Az angyal, ford. Lator László). Földi nő és szívrabló kerub között nem jöhet létre tartós kötelék, mert egymással összeegyeztethetetlen világban élnek, az egyik az örökkévalóságban, a másik az idő múlékony világában. Halandó asszony a démon vágyainak terébe csak áldozatként léphet be. Két világ drámai összeütközésének vagyunk a szemtanúi. Lermontov jobban bele tudott illeszkedni a büszke és sértett démon szerepébe, mint az angyaléba. A mondanivaló súlya nála nem az euangelikus motívumra, hanem a fenséges, szenvedő démonra helyeződik át. Azonos című poémájában az „iszonyú szépségű" démon halandó nőt csábít el, csókjával megöli a szépséges grúz apácát, de nem tudja megkaparintani a lány lelkét, Gábriel arkangyal isteni beavatkozásra elveszi tőle, és a nő kárhozat helyett megváltást nyer. „A Démon ottmaradt legyűrve, / Átkozva őrült álmait, / S megint, mint rég, ellenszegülve, / Magányosan repült az ürbe: / Szívében sem remény, se' hit!" (Radó György fordítása.) A magának abszolút szabadságot követelő „éter szabad gyermeke” kiűzetik a szent térből, örök vándorlásra, metafizikus otthontalanságra ítéltetik. Tamara halála azonban a Démon számára is tragikus, mert jóra törekvésének a kudarcát jelenti. Erkölcsi értelemben bűnös, metafizikai tekintetben viszont áldozat, részvétünk ezért neki is szól.

Gogol volt az első prófétája az orosz irodalomban a keresztény hagyományhoz való visszatérésnek, a művészet szakralizálásának. „Inkább keresztényt és embert lássatok bennem, mint irodalmárt.”16 Osztotta a szép dualitására vonatkozó mágikus-gnosztikus felfogást: a szép képes a világot megváltani, ha azonban gonosz erők hatalmába kerül, föltárja sötét arcát. A szép isteni természetű, de az ördög eltorzíthatja. A gogoli hősök még a szépségben is a lét metafizikai alapjainak kettéhasadtságát érzékelik, ami nyugtalanság és félelem érzését kelti bennük. Gogolnak a démoni és groteszk figurák ragyogóan sikerültek, de a példaként állítandó erényes női jellemek vértelenül és élettelenül kerültek ki a tolla alól. Tolsztojnál épp fordítva, azok az alakok plasztikusak, akiket szeretett, és azok síkszerūen laposak, akiket megvetett. Mély értelmú a kulcsmondat, amely a tűztől megmenekült Holt lelkek második kötetének egyik töredékében hangzik el: „szeress meg minket feketének, fehérnek mindenki megszeret.” Gogol bünükben is szerette az embereket, mert meglátta bennük a jó csíráit. Több volt, mint szatirikus, 
ő ugyanis a rossznak, a gonosznak nemcsak a pszichés/szociális megnyilvánulásait tárta föl, hanem a metafizikai mélységeit is. A rosszat az emberi természet mélyén rejlő kiirthatatlan tulajdonságnak tartotta, a létezés inherens részének, jóllehet gyökere transzcendens eredetű. Nem szüntethető meg, csak átmenetileg visszaszorítható a jó által. ${ }^{17}$

Ami Gogolnál látszólag társadalmi szatíra, ha alaposabban megvizsgáljuk, felismerjük benne a metafizikai magot. Vallotta, a tagadás csak egy eszmény nevében jogos, apokaliptikus vízióra épülő szatírát csak vallásos ember írhat. Sírkövére Jeremiás próféta átfogalmazott szavait vésték fel: „Keserű szókkal nevetek."

Regényhősnő nem lehet egydimenziós figura. Puskin, Lermontov, Gogol, Dosztojevszkij nőalakjainak, sőt még a tolsztojiaknak is, angyali vonásaik mellett vannak démoniak. ${ }^{18}$ Natasa „költői ördögfiókasága”, Anna Karenina démonikus szépsége, sugárzó érzékisége nem áll szöges ellentétben azokkal az értékekkel, amelyeket az érett Natasa, illetve Dolly és Kitty képviselnek: a házastársi hűséggel és az anyai örömökkel. Az örök női princípiumba mindkettő beletartozik. A démoniság nem annyira Annából, mint inkább a szenvedélyes szerelem irracionális természetéből fakad. Erósz a törvényen kívüliségnek (egy másik daimónnak engedelmeskedő magatartásnak) a szférája. ${ }^{19}$ Anna diabolikus vonásaira vetélytársnője, Kitty figyelt fel egy bálon: „gyönyörű ez a szép arc a maga elevenségében; de volt valami félelmes és vad is ebben a gyönyörüségben. 〈...〉 Van valami idegen, ördögi és gyönyörü benne." A regény korábbi változataiban Karenin és Vronszkij az „ördögi asszony” áldozata. A végleges változatban a két férfi közül egyik sem érdemli meg. $A$ regény rangját az adja meg, hogy Tolsztoj ugyanolyan mértékben hangoztatja a házasság intézményének a fenntartását és a szerelem szabadságának a jogát. A modernkori házasságtörő regényekben az élet mély, múvészi és filozófiai kérdéseit az átlag fölé emelkedő, tragikus sorsú nőalakok fogalmazzák meg, akik sem a férjükben, sem a szeretőjükben nem találják meg a teljességet. Tovább írják a tolsztoji (flaubert-i) szöveghagyományt, leleplezik a korábbi nőképek sztereotípiáit, újraértelmezik a nemi szerepeket és a személyiség határait a férfi-nő kapcsolatban. (Gondoljunk a férjét megmérgező Thérese Desqueyroux-ra, a Takaró Sanyit párnával megfojtó Kárász Nellire, a párját közvetve elpusztító Jadvigára.) Mindegyik szerelmi történet a női lélek rejtélyét bogozza, miközben még nagyobb rejtéllyé változtatja.

A szerelem és szépség költőjét, Turgenyevet kevésbé vonzotta az anima sötét jellegét, fenyegető érzékiségét megszemélyesítő végzet asszonya, amelyre számos példát találunk a világirodalomban: kimérák, szirének, sellők, Loreley (szláv megfelelője Ruszalka), Éj Királynője, Nasztaszja Filippovna, Lolita, akik végzetes bűverőt gyakorolnak a férfiakra. A démoni attribútumokkal felruházott, sötét tónusú (noire destinée) szépséges nőalakok (Klara, Valeria, Szofi, Szuszanna) csak kései, sejtelmes elbeszéléseiben bukkannak fel, ahol az "Örök nőiség” talányként metaforizálódik, a realista írásmód pedig fantasztikus tartalommal ötvöződik.

Csehov elégedetlen volt Turgenyev nőtípusaival: „összes asszony- és lányalakja elviselhetetlen a mondvacsináltságuk, és bocsásson meg, hamis voltuk miatt: Liza, Jelena nem orosz hajadonok, hanem valamilyen Püthiák, akik helyzetükhöz nem illő, nagyratörő jóslatokat és igényeket fogalmaznak meg."20 
Csehov nem változtatja át hősnőit Püthiává, titokzatos Szépséges Hölggyé, Szophiává. Következetesen lebontja az örök nőiség mítoszt, de minden írói szándéka ellenére, Tündéri című elbeszélése az orosz nő apoteózisává magasodik. A mű eredeti címe Dusecska, utal a nő átlényegülési képességére. Lelkecske (görögül pszükhé, latinul spiritus) lélek-szubsztancia, az ősvaló spirituális jelképe, a nőiség forrása (a lélek oroszul dusa - nőnemű, ezzel szemben a duh - szellem, hímnemű princípium). Dusecska maga a testet öltött lélek, azzá alakul át, amivé csak akar, bárkihez képes hasonulni. Átveszi és magáévá teszi férjei gondolatait, úgyhogy végül már mindent az ő szemükkel lát, az ő szavaikat szajkózza. Az elbeszélés hősnőjének egyik kapcsolatából sem született gyermeke, de aki szeret, annak szüksége van valakire, akit szerethet. Túláradó szeretetét végül egy gimnazista fiúra pazarolja. Nem az a fontos, hogy kit szeret, a fontos az, hogy szeret. Ő a női lét másik aspektusát, a lelki anyaságot, a Szophia-agapé szeretetet testesíti meg, a minden élővel való együttérzést. Párhuzamot vonhatunk közte és archetipikus előképe között, előbbit égi mása földhözragadt, alacsonyabb szintű megfelelőjének tartva. Ebben a példázatban a lélek általi bölcsesség kendőzetlenül tárulkozik föl előttünk, hogy mindenki szemügyre vehesse fénylő archetípusát Pszichében, és prototípusát Dusecskában. Az allúzió elrejti, ugyanakkor ki is nyilvánítja a történet spirituális lényegét: a szeretet a világ lelke. Őrzi eredeti értelmét, a szövegben azonban új megvilágításba kerül, és a rárakódott többletjelentéssel együtt fejti ki hatását. Az elbeszélésben nem vallási, hanem lelki csoda történik. Csehov közvetlenül nem vetett fel vallási témákat, de nála egy mindennapi eset olykor szakrális magasságokba emelkedik. Az olyan művészet, amely a feltétel nélküli szeretet apológiája, megérdemli a szakrális jelzőt: „szent és csodálatos Dusecska lelke, aki képes egész lényét odaadni annak, akit szeret. [Csehov] átkot akart szórni, a költészet istene azonban megtiltotta ezt és áldást parancsolt rá; ő pedig megáldotta, és önkéntelenül olyan csodálatos fénybe burkolta ezt a kedves lényt, hogy örökre példaképe marad annak, ami a nő lehet azért, hogy maga is boldog legyen és boldoggá tegye azokat is, akikkel a sors összehozza."21

"Óriási reményeink egyike, megújhodásunk egyik záloga az orosz nő" - jövendölte Dosztojevszkij. ${ }^{22}$ Hangsúlyozta a nők szerepét az elveszett éden visszaszerzésében. Hitt abban, hogy a nő a férfi számára átformáló, megváltó erővel rendelkezik. Ennek fényében újra kell értelmezni az irodalmi előképekben rögzült sztereotípiát, miszerint a nő sorsa a férfi; vagyis a nőt a férfihoz viszonyítva kell meghatározni és jellemezni. Dosztojevszkijjel kapcsolatban gyakran hangzik el a vád, hogy nála a nő nem hordoz önálló jelentéstartalmat, csupán sorsmomentum a férfi életében, külön sorsra való igény nélkül. Jóllehet, a nők nem eszmehordozók, fontos poétikai szerepet játszanak a férfihősök eszméléstörténetében. Az ikonnal vagy a bibliai archetípusokkal való kapcsolatuk révén egyfajta közvetítő szerepet töltenek be a profán és a szakrális világ között.

Dosztojevszkij a bestializálódás és az angyalizálódás folyamatát egyidejüleg ábrázolta. Nála a jó és a rossz kritériumai nem abszolútak: a rossz jóvá, a jó rosszá alakulhat. Az angyalarcú és az infernális nőtípusok nemcsak bináris ellentétbe, hanem korrelatív viszonyba is kerülnek egymással, mert a két oldal összetartozik: a démoni is része az egésznek, ugyanannak a dolognak a másik oldalát jeleníti meg. Az angyali és ördögi áthatják és kiegészítik egymást. Nasztaszja Filippovnában, Grusenykában, Katyerina Ivanovnában Dosztojevszkijnek sikerült egy személybe olvasztania az ellentétpárokat. Ambivalens lelki 
alkatú nőalakjai egy szempillantás alatt előző énjük ellentétévé, haragos Bellonává változhatnak: meghitt gyöngédségből gyülölködésbe csapnak át. És megfordítva: a démonok angyalarcú teremtményekké lényegülhetnek át, mert a démon legbensőbb lénye angyal. ${ }^{23}$

Dosztojevszkij hőseit az erősebb lét közelében, az örök szépség megpillantásakor, megrendültség, az iránta való lelkesültség és lenyűgözöttség egyidejű érzése hatja át. Lelkük megrémül, beleborzong egy istenihez hasonló instancia mindenhatóságának a megpillantásába, mert az isteni túl van az emberi határokon, ezért iszonyú. Az érzelmek paradoxitása akkor következik be, ha az ember váratlanul lénye határára érkezik, megpróbál áttörni lénye határain, miközben attól retteg, hogy a numinózus hatalom erőterében megsemmisülés fenyegeti. ${ }^{24}$

Nasztaszja Filippovna „fantasztikus, démoni szépsége” Miskint „teljesen elbűvöli”, ugyanakkor félelemmel tölti el:

„amikor csak a fényképét láttam, már akkor sem tudtam elviselni (...) én... félek az arcától - tette hozzá rémülten. (...)A szépség - talány." ${ }^{25}$

A démoni szép nemcsak megrémít, hanem hívogató, csábító büverővel ellenállhatatlanul vonz magához.

„A szépség félelmetes és rettenetes dolog! Félelmetes, mert meghatározhatatlan, meghatározni pedig azért nem lehet, mert az Isten csupa merő talánynak teremtette. Itt egymásba futnak a partok, itt együtt él minden ellentmondás. 〈...〉 Az a borzasztó, hogy a szépség nemcsak félelmetes, hanem titokzatos dolog is. Itt az ördög harcol az Istennel, és az emberek szíve a csatatér" mondja egyik regényhőse.

Dosztojevszkij a szép fogalmát az immanens síkról áttolja a transzcendens síkra. Számára a szép metafizikai entitás, a világ szofiánus voltának a testet öltése. A szép a legmagasabb, amit még el tudunk viselni. ${ }^{26} \mathrm{~A}$ legmagasabb rendű szép, amellyel az ember összeméri magát, ráébresztő hatású. A „ráeszmélés", az „igazságra ébredés" arra szólít fel, hogy az ember mozdítsa ki saját magát önmagából az Abszolútum felé. Emelkedjen fel a nem autentikus létből az igazi létbe. A szép átváltoztat.

Amit Dosztojevszkij művészileg ábrázolt (a szakrális szép megváltó szerepét), annak elméleti magyarázatát Szolovjovtól kapjuk. A jó igazolása címü tanulmányában föltárta a szépnek a metafizikával való bensőséges kapcsolatát: „A szép az anyag átváltozása a benne megtestesülő másik, anyagfölötti elv által.”27-28 A legmagasabb rendű jónak az érzékszervekkel közvetlenül föl nem fogható intellektuális szeretetet tekintette, mint amilyen a hazaszeretet, az emberiség szeretete, az istenszeretet (amor Dei intellectus). Szophia egyesíti a szeretet három formáját: az érzéki, az értelmi és a feltétel nélküli szeretetet. Az eszményi lét teljességét e három szubsztanciának az együttműködése biztosítja. Szophia minden létező igazi lényege, a mindenegység elve - consubstantia, amely kiegyenlíti az ellentéteket, összetartja és védelmezi a világot a gonosszal szemben. Az orosz vallásbölcseletben és ikonfestészetben a személyiség alapelvének számít. Azt jelenti, hogy ontológiailag minden lény az isteni bölcsességen és szereteten keresztül kapcsolódik egymáshoz. Szophia a mindent átölelő forma, összekapcsolja a férfielvet, a világteremtő igét 
(kosmos noetos) a női elvvel, a szenzibilitással és az alkotás formai tökélyével, amely a szépségben ölt testet (kosmos aisthetos). Szolovjov úgy tekintett Szophiára, mint a kozmikus és történelmi világrend organonjára, amely a Logosszal együtt a világmindenséget teremtő és fenntartó elv. Szophia-értelmezésében számtalan aspektust lehet megkülönböztetni, a kozmikustól kezdve a mágikuson át az eszkatologikusig. Témám szempontjából csupán egyetlen sajátosságát emelem ki, az „örök női” metaforát, amely a kortársakra és az utánuk következő szimbolista nemzedékre nagy hatást gyakorolt. Nevezetesen: „Az örök nőiség kultusza a gonosz, rabbá tevő nőiségtől való megszabaduláshoz vezető út volt." ${ }^{29}$

Az ezüstkor szimbolistáinál Szophia isteni és teremtményi lény egyszerre. Ha a logoszt testesíti meg, Krisztussá válik, ha nem, akkor Hold istenasszonnyá, bukott Szophiává változik. Az előző korszak íróinak moralizálását a szimbolistáknál a szépség kultusza váltja föl, amely a romantikusok das Ewig-Weibliche (versus das zeitlich-Männliche) kultuszából táplálkozott, akik a lét értelmét és titkát az örök nőiségben keresték. Szophiában az isteni bölcsesség és az örök nőiség egybeolvadását látták, akinek közreműködésével megvalósulhat az elveszett egység. Nem Krisztus volt rajongásuk tárgya, hanem Szophia, akit kabbalista és gnosztikus hagyományokat követve (Jakob Böhme, Swedenborg) az örök nőiség és az egyetemes szeretet tulajdonságaival is felruháztak. Szolovjov az örök nőiség eszményképét a Szivárványos kapuk leányában, a Napba öltözött asszonyban látta megtestesülni. Versei nem a világi Aphroditét dicsőítették, nem esztétikai célzattal jöttek létre, hanem numenikus ihletből.

Az ember nemcsak Isten, de a Sátán hívására is választ adhat. Szolovjov különbséget tett felülről jövő pozitív sugallat és alulról jövő ördögi megszállottság között. A szimbolisták második nemzedékének tagjai a hieratikus értékeket a travesztálás módszerével ellentétükbe fordították. Az evangéliumi szimbolikát profanizálták. A hagiográfiát demonológiába, a fehér mágiát fekete mágiába, a pluszt mínuszba, az igent nembe, Krisztust Antikrisztusba, az angyalit ördögibe, a megszentelt áldozatot istenkáromló áldozatba, a halálvágyat érzéki vágyba transzformálták. A megrendült erkölcsi abszolútumok helyébe ellenhősök léptek. Az antitípusok következtében az archetípusok még határozottabb jelleget öltöttek, mert minden negatívum csak a pozitívummal összehasonlítva negatívum. A bukásában is fenséges lermontovi démon földre hullt, varázserejét vesztett, „undok ördöggé" változott (Szologub). A szépségideál is leértékelődött: a mennyei Madonna alakját Belij Ezüst galambjában egy parasztmadonna (Matrjona), Brjuszov Tüzes angyalában pedig egy szodomai szépség (Madiel) váltotta fel. A diabolizmus dominánsan jelen van Remizov Ördögi színjátékában, Andrejev A Sátán naplójában, Szkrjabin zenéjében, Vrubel Démon-képein, Rubinstein azonos című operájában. Az Ég Királynőjének keresztény eszményképét fölváltotta a mitikus nyirkos földanya, Szophiát (az örök nőiség, a világ lelke szimbólumát) kiszorította az idő leánya, a babiloni parázna. A Szépséges Hölgy pedig az egyszerre égi tisztaságú és földi szenvedélytől izzó örömlány lefátyolozott képében jelenik meg egy városszéli kocsmában (Az ismeretlen nő). Florenszkij bírálta Blokot "esztétikai démonizmusáért”, amiért a lét esztétikai értékelését a morális értékek fölé helyezte. Remizov szerint Blok jobban tette volna, ha könyvének a Versek a Szépséges Szüzről (Стихи о Прекрасной Деве) címet adta volna, mivel az orosz nyelv szellemétől mélységesen idegen a "dáma” szó. Belij pedig azt rótta fel Bloknak, hogy Tizenketten címú poémája zárlatában nem Szophiát, hanem Krisztust szerepelteti. A Nyevszkij sugárúton tizenkét vörösgárdista (az új 
világot képviselő 12 apostol) menetel „vad viharban, mord borúban, fehér rózsa-koszorúsan, hógyöngyösen, hófehéren Jézus Krisztus megy az élen" (ford. Lator László). A vita közöttük Az ismeretlen nő és a Komédiásdi megjelenése után mélyült el, amelyekben Belij közös eszményeik kigúnyolását, az „örök női" archetípus lefokozását, a szakrális és a profán szféra összekeveredését sérelmezte.

Merezskovszkijt és a köréje csoportosuló „új-keresztény” filozófusok körét is élénken foglalkoztatta a kérdés: hol van a nő helye a teremtésben és Isten tervében. Nem filozófiai, hanem teozófiai kérdésekre keresték a választ. Számukra a teremtés női princípiuma éppolyan fontos volt, mint a férfié, nem fogadtak el egy olyan teológiát, amely az egyik felet kizárja. „A kereszténység elválasztotta a múltbéli örök Atyát a jövendőbeli örök Fiútól, a földi igazságot az égi igazságtól. Vajon a kereszténység után egyesíti őket a Lélek - az Örök Nőiség, az Örök Asszonyiság? Vajon kibékíti az Anya az Atyát és a Fiút?"30 Merezskovszkij Isten anyjának valóságos társmegváltó, anya-logosz szerepet tulajdonított. A női elvet negyedikként interpolálta a Szentháromságba, ezáltal a trinitást kvaternitássá változtatta. „Az egész pogányság, a Krisztus előtti kereszténység, csillapíthatatlan sóvárgás volt a Fiú után; a Krisztus utáni egész kereszténység csillapíthatatlan sóvárgás az Anya után. Az Atya nem mentette meg a világot, a Fiú nem menti meg, az Anya fog megmenteni; az Anya a Szentlélek." ${ }^{\prime 1}$ Merezskovszkij a földi és az égi igazság (a szent test és a szent lélek) egyenrangúságának és szintézisének a megvalósulását jósolta a jövő vallásában, a Harmadik szövetségben. „Mélységes hasadás, feloldhatatlan ellentét keletkezett a test és a lélek között, ugyanaz, amitől a kereszténység előtti világ is szenvedett, csak azzal a különbséggel, hogy ott, a pogányságban a vallás úgy próbált meg kijutni ebből az ellentmondásból, hogy a testet szentesítette a lélek rovására, itt, a kereszténységben pedig fordítva történt - a lelket szentesítették a test rovására." ${ }^{132}$

Merezskovszkij történelemfilozófiai nézetei a hegeli világszellem, illetve a szolovjovi mindenegység (всеединство) elvén alapulnak, amely axiómaként fogadja el, hogy a világ az eszményi és az anyagi, a véges és végtelen, az örök és a pillanatnyi dualizmusára épül, de a fejlődés folyamán ezek az ellentétek egybeesnek és föloldódnak. Megvalósul az omniunitas, vagy más néven a teljes egység. Merezskovszkijnak a világ háromosztatú szerkezetéről szóló érveit, amelyek a történelem fejlődését szembenálló princípiumok harcára, illetve az ellentétek szintézisben való feloldására korlátozzák, sem a teológusok, sem a történészek nem fogadják el. Cselényi István joggal állapítja meg, hogy a filozófiából nem vezet út a Szentháromsághoz. „A Szentháromság nem a lét dialektikus magyarázata, ahogy a német idealizmus próbálta megfejteni (tézis, antitézis, szintézis). Ez a dialektika már a háromság titkából kiinduló, utólagos eszmefuttatás volt." ${ }^{13}$

A test és a lélek dichotómiája a témája Nyikolaj Minszkij Szalóme eszméje cikkének, amelyben Oscar Wilde Salomé című drámájának hermeneutikai értelmezését adja. ${ }^{34} \mathrm{Az}$ orosz költő-kritikus szerint Szalóme és Keresztelő Szent János is az eszményi harmónia elérésére törekszik, csak különböző irányból közelítenek feléje. Szalóme azért vall kudarcot, mert szépségével nem tudja rabul ejteni János spirituális lényét, a férfi pedig azért, mert érzéketlen a testi szépség iránt, amelyben a bűn forrását látja. „Jochanán tragédiája abban van, hogy szép ember lévén nem látja a szépséget. Nem akarja látni, ezért 
keresztülnéz Szalóme lelkén." ${ }^{35}$ A bölcs mártírhalált halt egy csábos táncú lány miatt. A szent próféta nem veszi észre, hogy Szalóme vágyakozása a férfi szellemi-lelki lénye után az isteni széphez való vonzódását fejezi ki. Ez az oka, hogy „a test és a lélek szizigiuma” nem valósult meg. ${ }^{36}$ Mindez egybevág Merezskovszkij felfogásával, akinek a köréhez Minszkij is tartozott. Nevezetesen: a kereszténység nemcsak a lélek üdvözülésének a vallása, hanem a test szentségének az apoteózisa is. Az eszmény nem az aszkézis útján megvalósuló testetlen szentség, hanem az átlényegített szent test, amelyben megvalósul a test és a lélek misztikus egysége.

\section{Zárszó}

Szophia az isteni bölcsesség, a spirituális tudás női aspektusa, a feminin princípium testet öltése, aki inspiráló paradigmává válik az orosz irodalomban. Az írókat ellenállhatatlanul sarkallja új múvek létrehozására, amelyekben egy szöveg egy másik szöveget értelmez, átértelmez. Az isteni bölcsességbe és a megváltó nőiségbe vetett hit új mítoszként jelenik meg Zamjatyin Áradás (1929) című elbeszélésében, Cvetajeva Szonyecska regényében (1938), valamint Ulickaja Szonyecska (1992) című kisregényében, ahol a téma filozófiai-gondolati hátterét adja. A Szophia-mitologéma transzformációjának tekinthetjük Jurij Trifonov Ház a rakparton (1976), Tatyjana Tolsztaja Szonya (1984), Fazil Iszkander Szoficska (1997) című regényeit is. A főhőst mindegyikben Szonyecskának (Szofjának) hívják, aki mindig másik arcát tárja elénk, új jelentésárnyalattal gazdagítva az előbbieket, akiket az utóbbiak fényében szemlélve átértékeljük. ${ }^{37}$ Szerzőik profanizálják a Szophia-mítoszt, de nem képesek gyökeresen szakítani az orosz eszme szakrális vonulatával.

Viktor Jerofejev Az orosz széplány című regényének hősnője, bár más nevet visel, hangsúlyosan szofiánus vonásokat mutat, nála azonban a mennyei Szophia-mosoly posztmodern vigyorba torzul. ${ }^{38}$ Szophia mágikus megtestesülésből kitartott nővé alacsonyodik. Irina romlott, mégis ártatlan, a szerelemben kudarcot vallott, megalázott és meggyalázott ewigweibliche. Az eszményi szépre (például az „orléans-i szűzre”, Szent Johannára) történő utalásokban és szövegpárhuzamokban a regény kurtizán hősnője meglátja saját bukását, ami életének megváltoztatására ösztönzi. Még a legalantasabb nőben is él a madonnai eszménykép („,a szépség eszményi fényalakja”), amely élete egy bizonyos fordulópontján megkísérli szembe fordítani a szodomaival. Tragikus sorsát tekinthetjük úgy is, mint hiábavaló küzdelmét, hogy Szophiává válhasson. A szakrális szép a földöntúlival, a démoni szépség az erkölcstelen alvilági erőkkel áll kapcsolatban. Az előbbi megváltáshoz, utóbbi önpusztításhoz vezet. A hatalmától megfosztott, bukott szépség nem képes megmenteni a világot, maga szorul megváltásra. Szophia elsötétülése, transzcendens vonásaitól való megfosztása egy új apokalipszis eljövetelét jelzi, amelyben sötét, obszcén erők uralkodnak. A lefokozott mítoszok birodalmában a szakrális irodalom az apokrif felé tolódik. Korai azonban halotti beszédet mondani az orosz irodalom fölött, nem halt meg, jövője a múltjában van, amelyhez a (poszt)modern írók újító szándékkal visszanyúlnak. Egyszerre érvényesül a korábbi értékek megtartásának az igénye, ellentétük elismerésével együtt. Miközben devalorizálódik az életvilág (és a múvészi világ) egyik szegmense, valorizálódik a másik. 


\section{Jegyzetek}

${ }^{1}$ Nincs igazi múvészi alkotás a démon közreműködése nélkül. Lásd GIDE André: Dostoïevski. Articles et causeries. Paris: Gallimard, 1964: 142. o.

2 "Minden igazolható az ellentétével." A kabbalista En Soph, amely magában foglalja a végtelenséget és a végességet, önmaga egységét és tagadását, valamint Nicolaus Cusanus teológiájának és metafizikájának alapfogalma, az ellentétek egységének és egybeesésének az elve (coincidentia oppositorum), hatott Szolovjov filozófiájára.

${ }^{3}$ Bunyin I.: A szerelem nyelvtana. In: Bunyın Ivan: Az emésztố tǔz. Elbeszélések szerelemröl és halálról /Ford. Bagi Ibolya et al./. Budapest: Osiris Kiadó, 2003: 153. o.

${ }^{4}$ HAJNÁDY Zoltán: Sophia és Logosz. Az orosz kultúra paradigmatikus-szintagmatikus rendszere, bináris oppozíciói, leküzdésük alternatívái. Debrecen: Kossuth Könyvkiadó, 2002.; Szophia és Logosz a kozmikus és történelmi világrend organonjai. // Vallástudományi Szemle, 2017, №3, 71-85. o.

${ }_{5}$ „Az orosz népben nagyon erősen él a föld vallásos szeretete, nagyon mély rétege ez az orosz léleknek. A föld - a végső pártfogó. Alapkategória - az anyaság. Az Istenanya megelőzi a Szentháromságot, és szinte azonossá válik vele. A nép közelebb érezte magát a közvetítő, közbenjáró Istenanyát, mint Krisztust. Krisztusnak - a Mennyek Urának - földi alakja alig van megformálva. Személyes megtestesülést csak a föld-anya kар" Бєрдяєв Н.: Русская идея. Москва: Издательство В. Шевчук, 2000: 12. о.

${ }^{6}$ https://docplayer.hu/23325975-Az-orok-noi-variaciok-egy-temara.html

7 Vjacseszlav Ivanov szerint az orosz irodalomban az ördögnek két archetípusa honosodott meg: a rontó-pusztító ahrimáni mellett ott van ellenpontja, Lucifer, a fény bukott angyala, a jóra ösztönző rossz. (Raszkolnyikov, Ivan Karamazov a luciferi elvet képviselik, Szmergyakov, Peredonov stb. az ahrimánit.) A demonológia bővebb kifejtése szétfeszítené e tanulmány kereteit. Lásd erről: Венцлова Т. К демонологии русского символизма. In: Венцлова Т.: Собеседники на пиру. Москва: Новое литературное обозрение, 2012: 32-58. о.

${ }^{8}$ Bergyajev Ny. Dosztojevszkij világszemlélete /Ford. Baán István/. Budapest: Európa Könyvkiadó, 1993: 140. o.

${ }^{9}$ Lermontov ezt a bibliai idézetet választotta mottóként a Cserkeszfiú címú poémájához (ford. Arany László).

10 Пушкин, А. С.: Полное собрание сочинений в 10 mm. Ленинград: Наука, 1977-1979: VII. kötet, 22. о.

11 ФрАнК С. Л.: Этюды о Пушкине. Москва: «Согласие», 1999: 167-168. о.

${ }^{12}$ Bach sem restellte, hogy a testi gyönyörről zengő áriáját az egyik legszebb vallásos áriává alakítsa át.

${ }^{13}$ A félkegyelmú címú regényben Miskin herceg a tábornok lányának a kérésére elszavalja Puskin Szegény lovag címú versét, az A. M. D. (Ave Mater Dei) rövidítést azonban Nasztaszja Filippovna Baraskova nevének kezdőbetűire (N. F. B.) cseréli fel. Isten anyjának mennyei szépségét rávetíti a földi nő érzéki szépségére.

${ }^{14}$ A leghíresebb közülük Azazel, a bukott angyalok egyike, aki földi nőbe, Isztaharba lesz szerelmes. Zsidó hagyomány szerint ő csábította az asszonyokat ékszerviselésre, szépítkezésre. Bulgakov regényében Azazello adja a varázskrémet Margaritának, ravaszsággal ráveszi a nőt, álljon át a sötét oldalra. Azazél alakja gyakran túnik fel a demonológiával foglalkozó irodalomban (Milton, Eco, Rushdie, Saramago, Asimov, Akunyin).

${ }^{15}$ A nőket megszálló, a vetélytársakat elpusztító féltékenység és buja kéjvágy a témája Lermontov Asmódi lakomája címú költeményének. (Asmódeus a démonok és földi szellemek fejedelme, a legendák szerint alvó nőkkel hál. A keresztény világban az incubus babona alakjában őrződött meg. Nőnemú változata a succubus.) „Egy asszony szívét hoztam: még az égre / se bízta rá a titkait talán, / e szívecskét sokaknak elígérte, / de senkinek sem adta igazán. / Mindenkinek ártott, magát kivéve, / s a gonoszságához volt hű csupán" (ford. Lator László).

${ }^{16}$ Гоголь Н. В.: Собрание сочинений в 9 томах. Москва: Изд. «Русская книга», 1994: IX. kötet, 246. о.

${ }^{17}$ Bergyajev szerint még Istennek sincs hatalma a nem általa teremtett rossz felett. 
${ }^{18}$ Tolsztoj kései múveiben, a Kreutzer szonátában és az Ördögben a nő, mint egykor a korai egyházatyák szemében, instrumentum diaboliként jelenik meg. Összekapcsolódik a csábítás, a kísértés, a nagy veszedelem forrásával, következőleg, minden testiség kerülendő: omne corpus fugiendum est (Szent Ágoston).

19 «Эрос есть сфера беззакония.»

Lásd http://az.lib.ru/b/berdjaew_n_a/text_1949_samopoznanie.shtml (A magyar kiadásban ez a mondat kimaradt. Lásd BerGYAJEV, Nyikolaj: Önmegismerés/Ford. Gasparics Gyula, Kovács Erzsébet/. Budapest: Európa Könyvkiadó, 2002.)

20 Чехов А. П.: Полное собрание сочинений и писем в 30 томах. Соч. в 18 т. Письма в 12 т. Москва: Наука, 1974-1983: Письма, V. kötet, 174-175. о.

${ }^{21}$ TolsztoJ L.: Tanulmányok, cikkek, vallomások. In: Lev Tolsztoj múvei (1-10)/Ford. Gellért György et al./. Budapest: Magyar Helikon, 1967: IX. kötet, 802-804. o.

22 Достоввский Ф.М.Полное собрание сочинений в 30 томах. Ленинрад: Наука,1972-1990: XXIII. kötet, 28. о.

${ }^{23}$ Gnosztikus felfogás szerint a Sátán, mint Isten egyik angyala, aki „villámként zuhant alá az égből”, egykor szintén tökéletes volt, csak később vált ördöggé. A szent apokatasztaszis (az egyetemes megváltás) azt az elvet hirdeti, hogy Isten az újjáteremtés során minden teremtményt feltámaszt (még Káint és az Ördögöt is), és egyesülni fognak az istenséggel, amelyből egykor származtak.

${ }^{24}$ Rudolf Otto német teológus a teremtmény megrendült függőségérzését a teremtőtől a mysterium tremendum és a mysterium fascinans terminusokkal írja le 1917-ben megjelent múvében. Oтto Rudolf: $A$ szent /Ford. Bendl Júlia/. Budapest: Osiris, 1997.

${ }^{25}$ Dosztojevszkij F. M. A félkegyelmú /Ford. Makai Imre/. Budapest: Európa Könyvkiadó, 1981: 787, 791. o.

${ }^{26}$ „Mert mi a Szépség, ha nem annak a Rettentőnek a kezdete, melyet elviselünk még épp, s ha csodáljuk, azért, mert hagyja közönnyel léteznünk csak. Iszonyú minden angyal." (RILKE, R. M.: Duinói elégiák /Ford. Tandori Dezső és Tellér Gyula/, Budapest: Helikon, 1988: 7. o.) „Das höchste das wir noch grade ertragen” - Rilke rejtélyes szavainak értelme P. Sloterdijk hermeneutikája szerint a következő: „Semmi sem juthat közelebb az igazsághoz, mint amikor a szépség maga ül az elviselhetetlen alapja elé, mint törékeny elviselhetőség. 〈...〉»Azért adatott nekünk a múvészet, nehogy tönkre tegyen bennünket az igazság«." SLOTERDIJK P.: A gondolkodó a színpadon. A jó hír megjavításáról /Ford. Bendl Júlia és Kurdi Imre/. Budapest: Helikon Kiadó, 2001: 86, 200. o.

${ }^{27}$ Соловьев В. С.: Сочинения. Москва: Мысль, 1994, 205. о.

${ }^{28}$ Vö. Plótinosz szépségdefiníciójával: „A szépség az Egy örök ragyogásának átviláglása az anyagi jelenségen.”

${ }^{29}$ Бердяев Н.: Смысл творчества. Москва: Изд. Г. А. Лемана и С. И. Сахарова, 1916: 197. о.

${ }_{30}$ МереЖковский Д. С.: Полное собрание сочинений в 17 томах. Санкт-Петербург-Москва: Т-во Вольф, 1911-1913: Х. kötet, 33. o.

${ }^{31}$ MereskovszkiJ D. Sz.: Kelet titkai /Ford. Schmidt József, átdolg. Adamik Lajos/. Budapest: Holnap, 1992: 242. o. Az elképzelés, mely szerint a világtörténelem három egymást követő országlásra tagozódik, a 12. században élt Joachim da Fiore calabriai szerzetesig nyúlik vissza. Az Atya jegyében eltelt ótestamentumi és a Fiú jegyében eltelt újtestamentumi korszak után a történelemnek a lélek végső korszakában kell tetőznie. Merezskovszkij és múvészfilozófus barátai úgy gondolták, hogy a történelem egyes korszakai a Szentháromság egy-egy hiposztázisát tárják fel. A Szentlélek végül beteljesíti a háromságeszmét és újra megalkotja az axiomatikus egységet.

32 MerezskovszkIJ D.: Tolsztoj és Dosztojevszkij. In: Az orosz vallásbölcselet virágkora Tolsztojtól Bergyajevig /Vál. Török Endre, ford. Baán István/. Budapest: Vigilia, 1988, I. kötet, 165. o.

${ }^{33}$ CSELÉNYI István Gábor: A Szentlélek anyai arca. Budapest: L'Harmattan-Kortárs Női Reflexiók Fóruma-Anima Mundi, 2021: 82. o.

${ }^{34} \mathrm{~A}$ témát Flaubert is feldolgozta Heródiás címú novellájában. Nála a súlypont az erkölcstelen, felbujtó anyára, Wildenál a femme enfant és a femme fatale típust ötvöző „új nőideálra” esik. (Nabokov Lolitája is közéjük tartozik.)

${ }_{35}$ Минский Н.: Толстой и реформация. Идея Саломеи. // Золотое руно, 1908, № 6, 57. о.

${ }^{36}$ CIORAN S. D.: Vladimir Solov'ev and the Knighthood of the Divine Sophia. Waterloo, Ontario, Canada: Wilfrid Laurier University Press, 1977: 244. o.

37 Ковтун Наталья: Сонечки в новейшей русской прозе: к проблеме художественной трансформации мифологемы софийности. // LITERATŪRA Russian Literature. (Вильна), 2011 (Vol. 53), №2, 53-70. о. 
38 Irina szeretője, a „Szophia lovagjának” nevezett Szolovjov után kapta kereszt- és apai nevét: Vlagyimir Szergejevics (CAБO Т.: Родословная »Сонечки«. Szombathely: Szláv Történeti és Filológiai Társaság, 2015: 41. о.). A regény 2008-as moszkvai kiadásának címlapján Mona Lisa orosz népviseletbe öltözött portréja látható, hímzett pártás fejdísszel (kokosnyikkal), gyöngysorral a nyakában, Vlagyimir Szorokin ajánló sorai kíséretében: „Az orosz széplány $\langle. .$.$\rangle népi hősnő, akit mindenki$ szeret, és aki mindenkit különös tragikummal szeret. Vaginájának bergamot illata Oroszország örök nőiségének szimbólumává vált. A regény elolvasása után erősen szerettem volna megcsókolni Irina Tarakanovát a kulcscsontja között." 